\title{
A DIAGNOSIS OF STATISTICAL SERVICE COURSES IN MEXICO
}

\author{
CECILIA CRUZ LÓPEZ \\ Facultad de Estadística e Informática, Universidad Veracruzana \\ ceccruz@uv.mx \\ MARIO MIGUEL OJEDA RAMÍREZ \\ Facultad de Estadística e Informática, Universidad Veracruzana \\ mojeda@uv.mx
}

\begin{abstract}
Statistical education is a very important area of research because it builds knowledge and promotes innovation in the courses of this discipline. Based on the advances in this area, changes in the content and approaches of the courses at all educational levels have been promoted in several countries. In this study, we examine programs of introductory statistics courses at the higher education level, seeking to characterize the state of statistical education for non-statisticians in Mexico. The extent to which the Statistical Learning Goals (MAEs) were addressed was explored. Included in the study were 410 statistics course programs from various Mexican institutions. A checklist was constructed to assess the extent to which MAEs were considered in the programs; that is, indicators of the degree of consideration of each of the goals were constructed. Exploratory and descriptive analyses were carried out to identify the extent the goals were met, followed by multiple correspondence analysis to identify associations with the program identification variables. The results showed that the MAEs were applied very little in Mexico, especially those that refer to the development of statistical thinking and culture; the exceptions were the goals of organizing data, building tables and graphs, as well as calculating descriptive statistics. For all this, it was concluded that there is much work to be done on this issue in Mexico.
\end{abstract}

Keywords: Statistics education research; Innovation; Learning goals; Exploratory analysis; Multiple correspondence analysis; MAE

\section{INTRODUCTION}

\subsection{INNOVATION AND STATISTICAL COURSES}

It is unquestionable that statistics have evolved considerably in the second half of the twentieth century; therefore, the way in which this content is taught should also have evolved. However, it is a fact that at the end of the second decade of the 21st century, in many higher education institutions, (HEIs) statistics courses were still being taught as was done in the last century. This was especially the case for courses offered to professionals from other disciplines; that is, to those who require statistical thinking to develop the profession in the era of information and knowledge. It should be noted that these types of courses, called service courses, were the vast majority of statistics courses taught. This makes it increasingly urgent to innovate in this area.

Batanero (2019) argued that in higher education the teaching of statistics is generally the responsibility of professors with a very varied background: statisticians, engineers, economists, doctors, and mathematicians. This author emphasized that "Few of these professors are involved in research in stochastic education ...." However, there are many recommendations that describe "didactic innovations, mainly using intensive simulation, real data sets or visualizations; but few of these proposals are based on an in-depth study of student learning when using these tools" (p. 1). This points out that it is necessary to conduct more research to support innovation in statistics courses.

The term innovation arose formally in the 1960s. In the early 1990s, innovation changed its individualistic approach to that of more global reform (Castillo, 1989; Romero, 2003; 2008). In Mexico, the first innovation movements began to take place in the 1990s. However, this was particularly associated with the design and application of new curricular models and the implementation of new

Statistics Education Research Journal, 20(2), Article 10. https://doi.org/10.52041/serj.v20i2.360

(C) International Association for Statistical Education (IASE/ISI), December 2021 
prototypes and methodological strategies for teaching. Likewise, the innovation was intended to meet the demands of Mexican education before a globalized society, called the knowledge society (DíazBarriga, 2005).

Within statistical education, recognition has already been achieved that statistics is a methodology used in research and applied to all areas of knowledge. It also helps the formation of scientific thinking because it encourages analysis and decision making based on information extracted from relevant data. It is said that this way of thinking and acting is supported by a statistical thought, which is desirable to be well developed. Juárez and Inzunsa (2014) specify that the incorporation of statistics into the curriculum has generated interest, which has led to researchers and institutions in various countries have been given the task of developing evaluation instruments to measure learning and reasoning of students. Thus, statistical education has become a field of study needed to improve teaching. This is because internationally there have been changes caused by educational reforms, so the discipline is trying to evolve in its educational processes. In this regard, Hassad (2003) mentions that teaching and learning to statistics continues to generate a great debate about content and pedagogy, in the midst of an ongoing reform. In recent decades the number of countries that have been concerned about this situation has increased. This is in acknowledgment of how important a basic statistical culture is at an early age. The importance of statistics at basic levels of education is now recognized, in addition to emphasizing that statistics is useful in many professions, because it encourages critical reasoning based on the assessment of objective evidence.

Some of the first measures to improve statistical education have been to end the mathematized courses and ensure statistical concepts are no longer taught as recipes. Another innovative process already incorporated was the use of statistical software. Batanero (2001) and Behar and Ojeda (2016) indicated that the use of computer resources facilitates the learning of statistics, since thanks to this, problem-solving skills and data interaction are developed. In such a way that the use of technological resources has been seen as educational innovation tools. Similarly, Palomo et al. (2006) emphasize that the innovative nature of teaching has been influenced by the use of ICT, as well as ICT being a resource to motivate students and for teachers to seek new ways of teaching. All these advances in teaching this discipline have benefited from applying innovative teaching, the most important is the project-based approach. Bailey et al. (2013) suggested that students learn statistics effectively by carrying out projects in which they actively perform comprehensive tasks focused on statistical research, as long as it is focused on the context of a real problem.

Also, since the last century, various international associations were created with the purpose of promoting the development of statistical education. One of the most important was the International Association of Statistical Education (IASE), which organized the International Conference on Teaching Statistics (ICOTS) every four years. The opportunity to report the many of the proposals in this context have provided extraordinary results in the significant learning of students towards statistics and their usefulness in the professional field, in addition to the fact that they are leading students towards data science (Biehler, 2018; Izumi \& Hatayama, 2018; Lyford \& Kaplan, 2018; McNamara, 2018).

Countries like the United States of America have several years of encouraging statistical thinking not only in their basic levels of education but also in their preschool system. In Mexico, the inclusion of statistical concepts at basic levels is recent. The new programs approved by the Ministry of Public Education (SEP) already show content that develops statistical literacy from the first grades of primary education. However, statistical education in Mexico is not newly created. It has been developed from the upper middle education system within the mathematics courses, and in HEIs most professional careers consider at least one statistical course. The question is, "How appropriate are the programs that are followed to teach these courses?" It is assumed that there is a problem in this regard, but it has not been evaluated. To increase the quality of the courses to improve the levels of dissatisfaction of young people upon completion, it is necessary to promote the innovations implemented. However, the change in statistical education will only happen when teachers are convinced that statistics is a useful discipline and that in turn, they are adequately prepared to teach it at their respective levels (Juárez \& Inzunsa, 2014). 


\subsection{THE PROGRAMS OF THE COURSES AND THE MAE}

At university level, most students study introductory statistics courses-also called service courses - for study in disciplines such as psychology, business, economics, social sciences, and engineering. Statistics are also considered in most math schools and in degrees in statistics, which are referred to as statistics courses for statisticians. Introductory statistics courses for professionals in other disciplines differ by the level of mathematical training required, the coverage of probability theory, the selection of topics and approaches, and the use of technology.

Gal and Garfield (1997) specify that there are common objectives in the teaching of statistics at various levels and educational contexts; that is, what students want to learn and what they should be able to do with their knowledge at the end of the course. This is considered a unique objective for statistical education. This objective is achieved when students finish a statistics course and become citizens capable of understanding and dealing with uncertainty, variability and statistical information in the world around them. This is to empower them to effectively participate in an informed society, as well as contribute to the production, interpretation and communication of data and statistical information in their professional life. These assertions are a vision of knowledge in a broad sense, whose achievement can be extended for several years or levels of schooling through statistics courses.

From this vision, eight goals for learning statistics (MAEs) are presented; they are called "basic" as they relate to the first phase in which students face statistics at most levels of education. The MAEs are oriented to the design and development of the introductory courses. This proposal has been taken as an international innovation technique because it establishes the common objectives that must be met when starting in statistics. The MAEs are oriented to the student development of statisitcal reasoning and thinking. The goals apply to any discipline and are presented succinctly in Table 1.

\section{Table 1. Statistical learning goals proposed by Gal and Garfield(1997).}

\begin{tabular}{|c|c|}
\hline Goals & Topics \\
\hline $\begin{array}{l}\text { M1. Understand the purpose } \\
\text { and logic of statistical } \\
\text { investigations. }\end{array}$ & $\begin{array}{l}\text { (a) the existence of variation in data; (b) the need to describe populations; (c) } \\
\text { the need to summarize data to identify trends; (d) the need to study the sample } \\
\text { instead of the population (inference); (e) the logic behind the sampling } \\
\text { processes; (f) the notion of measurement error and its control; (g) the need to } \\
\text { find causal factors that explain variation; (h) the logic behind the studies } \\
\text { (experimental, observational) to see causal processes. }\end{array}$ \\
\hline $\begin{array}{l}\text { M2. Understand the process } \\
\text { of statistical research. }\end{array}$ & $\begin{array}{l}\text { (a) The formulation of research questions; (b) the general planning of the } \\
\text { study; (c) the data collection and organization phase; (d) the importance of } \\
\text { summarizing, exploring and analyzing data; (e) interpret the results in the light } \\
\text { of research questions; (f) discuss conclusions based on results. }\end{array}$ \\
\hline $\begin{array}{l}\text { M3. Acquire skills in basic } \\
\text { statistical procedures. }\end{array}$ & $\begin{array}{l}\text { (a) Organize the data; (b) construction of tables and graphs, useful figures; (c) } \\
\text { calculate descriptive statistics. }\end{array}$ \\
\hline $\begin{array}{l}\text { M4. Understand } \\
\text { mathematical relationships. }\end{array}$ & $\begin{array}{l}\text { (a) The interpretation; (b) the mathematical ideas associated with the graphics; } \\
\text { (c) explain how the mean is affected at extreme values; (d) deduction of } \\
\text { formulas. }\end{array}$ \\
\hline $\begin{array}{l}\text { M5. Understand chance and } \\
\text { probability. }\end{array}$ & $\begin{array}{l}\text { (a) Using examples of gambling; (b) using computational simulation; (c) } \\
\text { developing models to simulate events; (d) discussing concepts that are related } \\
\text { to chance and uncertainty in everyday life; (e) exercising the understanding of } \\
\text { events that happen in the world, and information in the media; (f) demonstrate } \\
\text { that sometimes intuition is incorrect and leads to wrong conclusions. }\end{array}$ \\
\hline $\begin{array}{l}\text { M6. Develop interpretive } \\
\text { skills and statistical culture. }\end{array}$ & $\begin{array}{l}\text { How reliable are your measuring instruments? How representative is the } \\
\text { sample? What are the potential biases? }\end{array}$ \\
\hline $\begin{array}{l}\text { M7. Develop skills for } \\
\text { statistical communication. }\end{array}$ & $\begin{array}{l}\text { It consists of conveying results convincingly and constructing your own } \\
\text { arguments, which must be based on the data. }\end{array}$ \\
\hline $\begin{array}{l}\text { M8. Develop appreciation for } \\
\text { statistics. }\end{array}$ & $\begin{array}{l}\text { Realize that the statistical research process can lead to improved conclusions } \\
\text { and perform much more sustained actions that produce better results in } \\
\text { scientific practice. }\end{array}$ \\
\hline
\end{tabular}


MAEs can be divided into two groups: those that emphasize the generation of statistics; that is, in the know-how, in the use of techniques, the logic that the procedures follow, and the understanding of the purposes. This first group is defined by the first five goals, the second focuses the activities on the importance of decisions, communication skills, the correct reporting of results, as well as the reflection and questioning of one's own conclusions and other investigations. This group is defined by the Goals 6, 7 and 8. We can name the groups, respectively, in goals associated with "know-how" and goals to "know how to think". These eight goals highlight a change in the point of view of traditional teaching, seeks to end courses with the mathematical approach that is still included in many of them and move towards only us mathematics as a support tool.

As background to this research, we have in the first instance the work of Garfield and Gal (1999) where they encouraged the professors who teach the introductory statistics courses to self-evaluate based on the MAE outcomes and offer a series of innovative approaches that have been used in these courses. They conclude that if these innovative techniques are followed, the students can improve their learning significantly.

Another closely related investigation was the one carried out by Méndez and Ojeda (2006), where they resumed the MAE and evaluated a group of professors of statistics of the upper and upper middle level who participated in a colloquium of teaching statistics. They found an inadequate performance of teachers related to the understanding of key concepts of the statistical methodology. They also emphasized that the culture of self-evaluation should be promoted among teachers so that teachers become aware of their abilities and deficiencies in the characterization of the statistical methodology.

Figueroa and Larios (2005) proposed a change in the content of an introductory statistics course based on the proposal of a group of experts from the American Statistical Association and the Mathematical Association of America. They also took into account some considerations recommended by Ballman (1997), Garfield (1995), and Moore (1993). In the research they proposed a teaching methodology that was based on three aspects: 1) propose activities that lead the student to the concepts, instead of teaching them as a recipe; 2) use software that allows them to interact with the data; and 3) include projects in which students generate their own data, analyze and report them.

Gundlach et al. (2015) compared an introductory course of statistics at university level in different teaching formats (traditional, online, and inverted classroom) that lasted 16 weeks. They demonstrated that the students of the online and inverted classroom course performed better than the students of the traditional course. They concluded that the inverted and combined classrooms presented greater evidence of learning, as well as greater motivation and commitment on the part of the students.

Vivacqua et al. (2018) proposed collaborative activities for students to actively participate in an advisory laboratory, where they worked in multidisciplinary groups of professionals from other fields solving social problems through statistical methodology, which allowed them to acquire knowledge and skills of the discipline under proper supervision. During their experience in the activity, the students wrote a research report and presented it at a conference to illustrate the learning of statistical methods and to develop their professional attitude. This proved to be an effective form of innovation, which provided the opportunity to exchange best practices.

When innovating in the courses, the promotion and development of knowledge, skills and abilities that allow students to develop competencies for the workplace must be established in the programs. A competition, according to Boterf (2000), is the ability to mobilize and properly apply in the work environment own resources, among which are skills, knowledge and attitudes, as well as resources from the environment to produce a defined result. Therefore, a program of a statistical service course is a formative proposal for the student to obtain the specific competencies that the workplace demands. Batanero $(2000,2019)$ recommended that the analysis of the curriculum be carried out to take actions that lead to the improvement of the teaching-learning process of statistics. Following this line of recommendations in this study, the analysis of the programs of the statistics courses of different HEIs of Mexico was carried out to detect didactic actions that improve the statistics courses in the institutions of the country.

Recently, the authors of this work have explored the impact of the MAEs considering the opinion of students and teachers in statistical service courses, finding that the statistics courses were focused on the use of techniques and procedures to obtain information, but had little emphasis on developing reflection, the communication of results, and the critical disposition for conducting statistical investigations. Therefore, being focused only on teaching methods and techniques, the development of 
statistical thinking in the student was neglected (Cruz \& Ojeda, 2016; 2018). Therefore, the strategy of this research focuses on examining the programs of study of introductory statistics courses in HEIs of Mexico, seeking to characterize the status of these educational actions, considered as the benchmark for evaluation of the MAEs.

\section{METHODS}

Included in the study are 410 statistical course programs, which were available on the internet during 2016. A web page (https://www.altillo.com/universidades/universidades_mex.asp) that contained the most complete list of universities in Mexico by region was located. From that list the links of the official pages of the Mexican HEIs were obtained, in their modalities of universities and technology institutes. The list of programs collected by institution is presented in Table 2 .

Table 2. Programs collected by institution.

\begin{tabular}{lr}
\hline \multicolumn{1}{c}{ Institution } & Number of programs \\
\hline Instituto Politécnico Nacional (IPN) & 19 \\
Instituto Tecnológico Autónomo de México (ITAM) & 10 \\
Instituto Tecnológico de Aguascalientes (ITA) & 9 \\
Instituto Tecnológico de Cancún (ITCANCUN) & 6 \\
Instituto Tecnológico de Chapala (ITCHAPALA) & 10 \\
Instituto Tecnológico de Chetumal (ITCHET) & 9 \\
Instituto Tecnológico de Ciudad Guzmán (ITCG) & 12 \\
Instituto Tecnológico de Coacalco (IT & 18 \\
Instituto Tecnológico de Comitán (ITCOM) & 14 \\
Instituto Tecnológico de Durando (ITD) & 5 \\
Instituto Tecnológico de El Grullo (ITGRULLO) & 10 \\
Instituto Tecnológico de Ensenada (ITE) & 7 \\
Instituto Tecnológico de Mexicali (ITM) & 2 \\
Instituto Tecnológico de Nuevo León (ITNL) & 8 \\
Instituto Tecnológico de Pabellón de Arteaga (ITPAB) & 2 \\
Instituto Tecnológico de Tijuana (ITT) & 11 \\
Instituto Tecnológico de Tuxtla Gutiérrez (ITTG) & 9 \\
Instituto Tecnológico el Llano (ITLL) & 3 \\
Universidad Autónoma de Baja California (UABC) & 29 \\
Universidad Autónoma de Chihuahua (UACH) & 16 \\
Universidad Autónoma de Colima (UAC) & 14 \\
Universidad Autónoma de Guadalajara (UDG) & 20 \\
Universidad Autónoma de San Luis Potosí (UASL) & 21 \\
Universidad Autónoma Metropolitana (UAM) & 10 \\
Universidad de Michoacán (UMICH) & 13 \\
Universidad de Sonora (UNISON) & 29 \\
Universidad Emiliano Zapata (UEZ) & 10 \\
Universidad Nacional Autónoma de México (UNAM) & 37 \\
Universidad Veracruzana (UV) & 47 \\
\hline & \multicolumn{1}{c}{ Total of programs collected } \\
\hline
\end{tabular}

An exhaustive review of each program was conducted and how much the MAEs were considered was evaluated. The eight goals were used as dimensions and as variables to explore the various aspects that should be taken into account, as indicated in Table 1. In the column Topics, three classification categories were used: (1) Not considered, (2) Considered but not sufficiently and (3) Considered sufficiently, as indicated in Table 3, in the line corresponding to Mi. The eight goals MAE were 
evaluated in each program after reviewing each topic mentioned in each goal. The indicators were labeled with M1, M2, ..., M8; these were scaled from 0 to 100 , to indicate how well each goal was attended. After exploratory analyses, a multiple correspondence analysis (MCA) was performed.

Table 3. Explanation of variables considered for data analysis.

\begin{tabular}{|c|c|c|}
\hline Variable & Description & Scale and categories \\
\hline State & $\begin{array}{l}\text { State of the Mexican Republic to which the institution } \\
\text { belongs. The states were listed in alphabetical order. }\end{array}$ & $\begin{array}{l}\text { Nominal } \\
\text { 1: Aguascalientes } \\
\text { 2: Baja California } \\
\text { 3: Chiapas } \\
\ldots \\
\text { 15: Veracruz }\end{array}$ \\
\hline Course & Classification of courses according to name. & $\begin{array}{l}\text { Nominal } \\
\text { 1: Biostatistics } \\
\text { 2: Statistics } \\
\text { 3: Probability \& Statistics } \\
\text { 4: Statistical methods }\end{array}$ \\
\hline Area & Indicates the academic area to which the program belongs. & $\begin{array}{l}\text { Nominal } \\
\text { 1: Social Science } \\
\text { 2: Exact Science } \\
\text { 3: Economic- } \\
\text { administrative } \\
\text { 4: Biological -Agricultural } \\
\text { 5: Health Science }\end{array}$ \\
\hline Sum_A $i^{*}$ & Is the sum of the values of the items of Goal $i$. & Numeric \\
\hline $\mathrm{IMi}^{*}$ & $\begin{array}{l}\text { The rating created with the variable Sum_Ai, on a scale of to } \\
0 \text { to } 100 \text {, which indicates how much the goal was met. }\end{array}$ & $\begin{array}{l}\text { Numeric } \\
\text { (Percent) }\end{array}$ \\
\hline $\mathrm{Mi}^{*}$ & $\begin{array}{l}\text { The index of consideration of Goal } 1 \text { created with base to } \\
\text { the IMi variable, coded in } 3 \text { categories: } 1=\text { Not considered; } \\
2=\text { Considered but not sufficiently; } 3=\text { Considered } \\
\text { sufficiently. }\end{array}$ & $\begin{array}{l}\text { Ordinal } \\
1: 70 \% \text { or less } \\
2: 71 \% \text { to } 89 \% \\
3: 90 \% \text { or more }\end{array}$ \\
\hline Sum_Global & The global sum of the values of the total items. & Numeric \\
\hline IMT & $\begin{array}{l}\text { The rating created with the Sum_Global variable. On a scale } \\
\text { of } 0 \text { to } 100 \text {, which indicates how much the total goals are } \\
\text { met. }\end{array}$ & $\begin{array}{l}\text { Numeric } \\
\text { (Percent) }\end{array}$ \\
\hline Ind_Global & $\begin{array}{l}\text { The index of consideration of the goals created with base to } \\
\text { the IMT variable, coded in } 3 \text { categories: } 1=\text { Not considered; } \\
2=\text { Considered but not sufficiently; } 3=\text { Considered } \\
\text { sufficiently. }\end{array}$ & $\begin{array}{l}\text { Ordinal } \\
\text { 1: } 70 \% \text { or less } \\
\text { 2: } 71 \% \text { to } 89 \% \\
\text { 3: } 90 \% \text { or more }\end{array}$ \\
\hline
\end{tabular}

\section{RESULTS}

The distribution of the programs collected by academic area was: Exact 51\%, Economic 25\%, Agricultural and Social 9\% and 7\% Health Sciences. The distribution of the types of courses was 49\% probability and statistical courses, $40 \%$ statistics, $7 \%$ biostatistics and $4 \%$ statistical methods. To evaluate the MAEs in the programs, the frequencies of the values of each of the items were obtained to see which aspect was the one that was not met in each goal, taking into consideration those that had more than $30 \%$ in the category of "Not considered". The results are shown in Figure 1. 


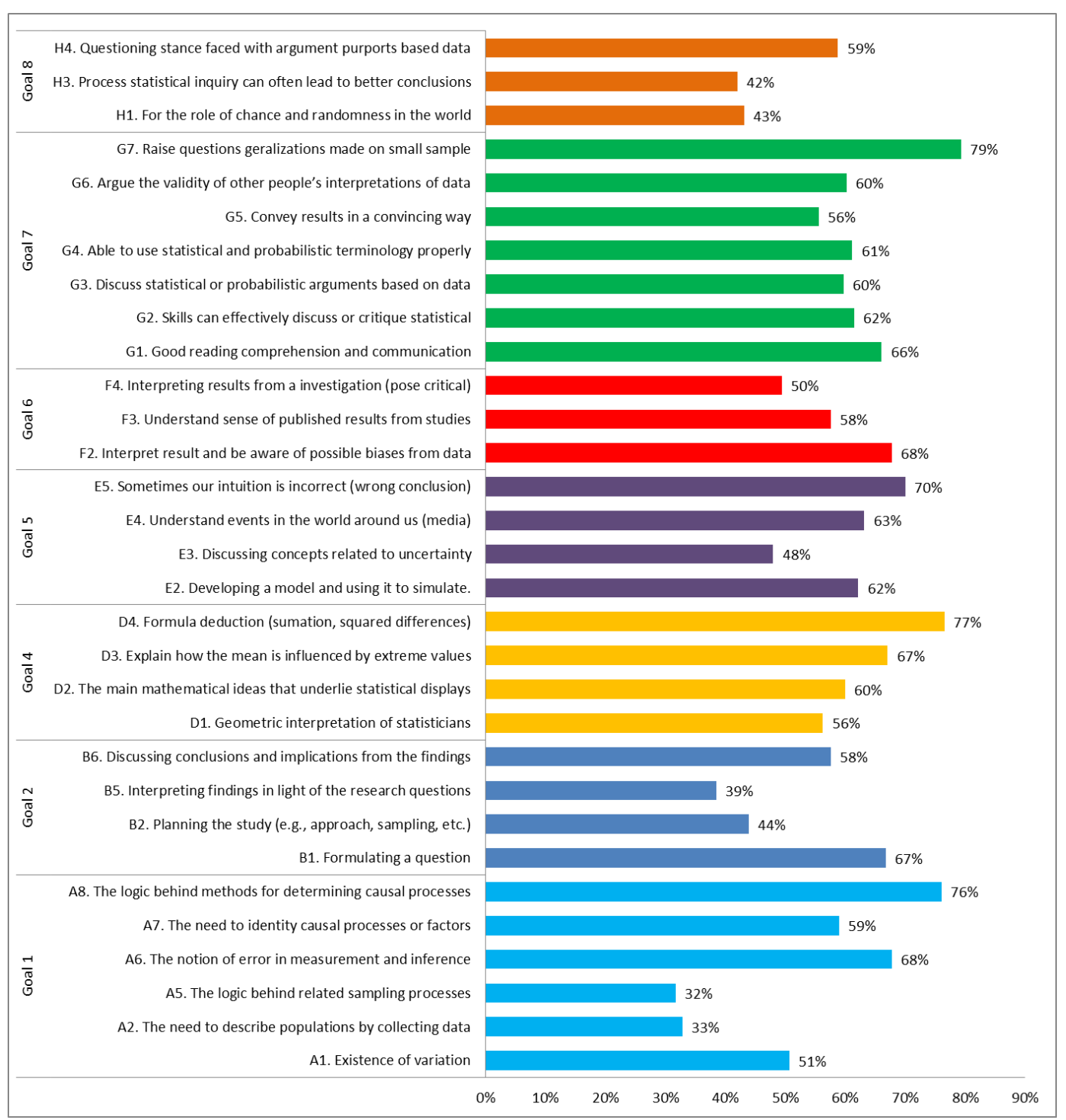

Figure 1. Aspectos of the MAEs that are not considered in the programs.

In Figure 1, the lowest values are the ones that were most attended, and the highest values are the ones least attended - note that Goal 3 is not included in the figure. Goal 3 is not included because the category "Not considered" did not exceed $30 \%$. Recall that Goal 3 is about the skills of calculating descriptive measures and graphing, which was in the vast majority of programs; therefore, was the only goal fully met.

When reviewing Figure 1, most aspects appear as not contemplated within the programs; any aspect not taken into account and its frequency can be observed. It is noted that the aspects with higher frequencies of "Not considered" are: Aspect 6, 7 and 8 of Goal 1; Aspect 1 and 6 of Goal 2; all aspects of Goal 4; Aspects 2, 4 and 5 for Goal 5; 2, 3 and 4 for Goal 6; all aspects of Goal 7; and finally, Aspect 4 of Goal 8. This clearly indicated that important aspects of the research process were being omitted, such as: asking questions and discussing results, revealing that only data processing is being emphasized. The understanding of uncertainty was also being omitted; only the calculation of probabilities was being promoted, without highlighting the importance of stochastic phenomena in the real world. Another aspect left unattended was the interrogation cycle, which encourages new questions to arise before the answers obtained; that is, that the interpretation of the results must always be assumed with a critical attitude. Likewise, the raw material with which statistical thinking works is the information contained in the data, so it is necessary to produce implications, indications and conjectures about the situation of interest. For this reason, it is necessary to effectively communicate the results, to 
be able to establish connections among existing knowledge and the results of the analysis; in this way significant conclusions can be obtained. Finally, the promotion of the axiological dimension of statistical thinking was excluded from the programs, such as appreciation for the discipline and the values required to understand its usefulness in society.

A global index was also obtained to be able to categorize the total of the programs into three categories; the results show that $16.3 \%$ of the programs practically do not consider the MAEs, $65.9 \%$ consider them poorly, and only $17.8 \%$ consider them sufficiently. It means that about 2 out of 10 programs are the only ones that consider MAEs in an acceptable way: a rather bleak picture.

In order to identify institutions with attention to the goals, an MCA was carried out for each of the seven goals included in Figure 1. Each goal was considered in three categories, as indicated in Table 3 in the row corresponding to Mi. Academic Area, Course, Institution and Goal were also analyzed. Figure 2, corresponding to Goal 1, shows that there is an association (blue circle) between the following categories. Goal variable in its category: Not considered; with Area: Health Sciences; Course: Biostatistics; and Institution: UEZ and UNISON. Another relationship was seen in the analysis (yellow circle) of the categories of variable Goal: It is considered but not enough; Area: Social and Agricultural Sciences; Institutions: ITAM, UNAM, UACH, UDC. A third association (green circle) occurred among the categories of the variable Target: It is sufficiently considered; Area: Economic and Exact; Course: Probability and Statistics; and Institutions: Technological, from Aguascalientes, Baja California, Chiapas, Jalisco, Nuevo León and Quinta Roo.

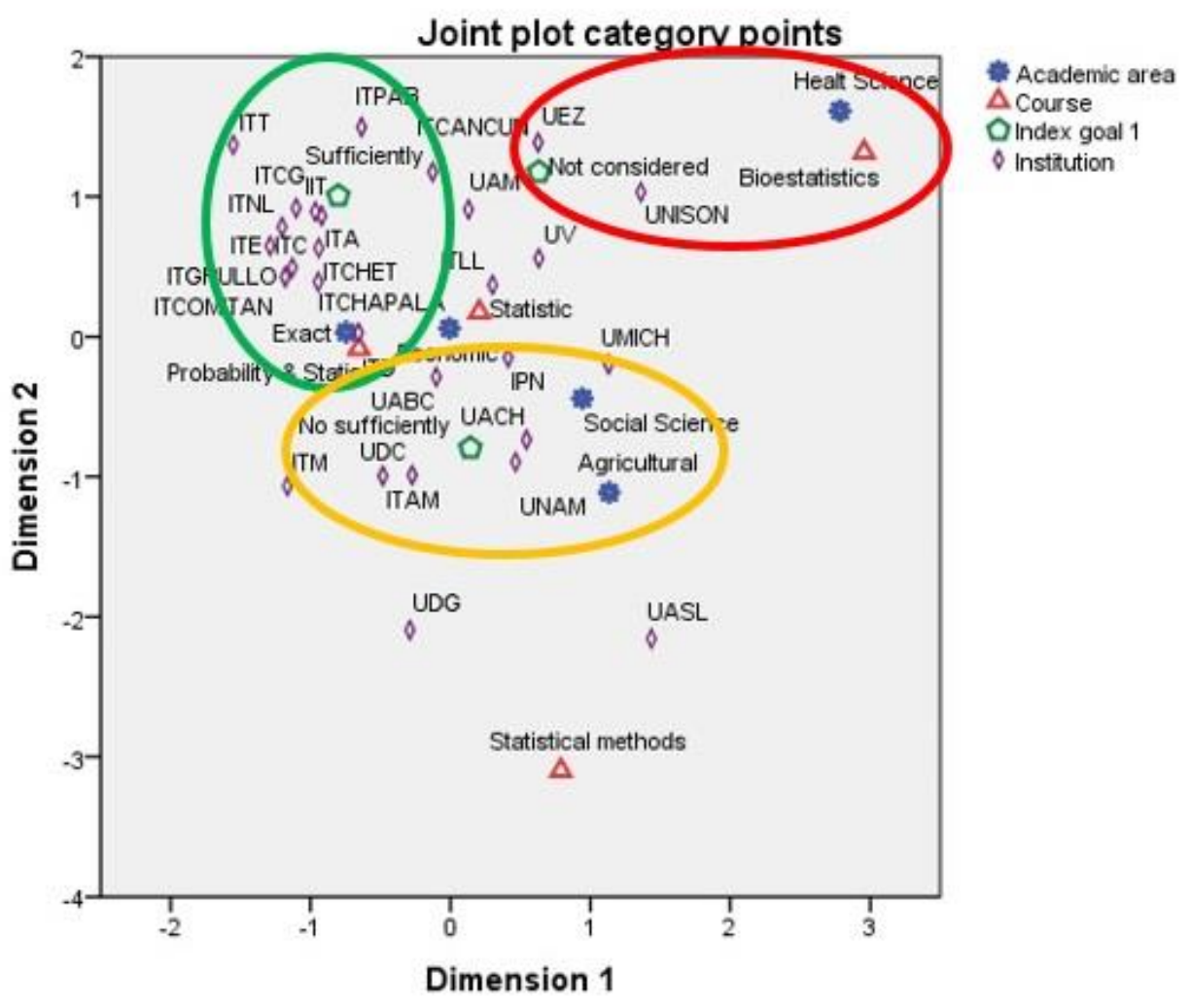

Figure 2. Correspondence multiple analysis between Area, Course, Institution and Goal 1.

The following groups are identified: (1) in the area of health sciences that mostly have biostatistics courses, which do not consider the concepts of variation, sampling, inference, experimentation at the UNISON and UEZ universities; (2) from the social and agricultural areas, at ITAM, UNAM and UACH universities, which consider them but sufficiently; and (3), the most numerous, made up of the areas of economic and exact sciences with probability and statistics courses that do consider objective 1 in their programs; that is, they are the programs that take into account concepts such as: the understanding of variation, the importance of inference studies, sampling and experimentation. This occurred in the 
technological institutes of Nuevo León, Chapala, Chetumal, Aguascalientes, from Tijuana, among others. The same analysis was run for the remaining goals and the most relevant results are shown in Figure 3.

\begin{tabular}{|c|c|c|c|c|}
\hline Goal & Institution & Area programs & Course & Goal category \\
\hline \multirow[t]{3}{*}{1} & UEZ, UNISON & Health Sciences & Biostatistics & Not considered \\
\hline & $\begin{array}{l}\text { ITAM, UNAM, } \\
\text { UACH, UDC } \\
\text { IPN, UABC }\end{array}$ & $\begin{array}{l}\text { Social Sciences, } \\
\text { Biological -Agricultural }\end{array}$ & Statistic & $\begin{array}{l}\text { Considered but } \\
\text { not sufficiently }\end{array}$ \\
\hline & $\begin{array}{l}\text { ITNL, ITE, ITCG, } \\
\text { ITCHET, ITC, ITA, } \\
\text { ITCHAPALA }\end{array}$ & $\begin{array}{l}\text { Economic-Administrative, } \\
\text { Exact Sciences }\end{array}$ & $\begin{array}{l}\text { Probability } \\
\text { \& Statistic }\end{array}$ & $\begin{array}{l}\text { Considered } \\
\text { sufficiently. }\end{array}$ \\
\hline \multirow[t]{2}{*}{2} & $\begin{array}{l}\text { ITLL, ITCANCUN, } \\
\text { UMICH, UABC, } \\
\text { UNAM }\end{array}$ & Social Sciences & Statistic & Not considered \\
\hline & $\begin{array}{l}\text { ITNL, ITGRULLO } \\
\text { ITCHAPALA, } \\
\text { ITCOMITAN, ITT, } \\
\text { IIT, ITCG, ITCHET }\end{array}$ & Exact Sciences & $\begin{array}{l}\text { Probability } \\
\text { \& Statistic }\end{array}$ & $\begin{array}{l}\text { Considered } \\
\text { sufficiently. }\end{array}$ \\
\hline \multirow[t]{2}{*}{4} & $\begin{array}{l}\text { ITCHET, UDC, ITD } \\
\text { UDG, ITPAB, IIT }\end{array}$ & Economic-Administrative & Statistic & $\begin{array}{l}\text { Considered but } \\
\text { not sufficiently }\end{array}$ \\
\hline & $\begin{array}{l}\text { ITNL, UAM, UV, } \\
\text { ITE, ITCHAPALA }\end{array}$ & Exact Sciences & $\begin{array}{l}\text { Probability } \\
\text { \& Statistic }\end{array}$ & $\begin{array}{l}\text { Considered } \\
\text { sufficiently. }\end{array}$ \\
\hline \multirow[t]{3}{*}{5} & $\begin{array}{l}\text { UACH, UNISON, } \\
\text { UNAM, UAM, IDC }\end{array}$ & Biological -Agricultural & $\begin{array}{l}\text { Statistical } \\
\text { Methods }\end{array}$ & Not considered \\
\hline & $\begin{array}{l}\text { UABC, ITC, ITE, } \\
\text { ITNL, ITA }\end{array}$ & Exact Sciences & $\begin{array}{l}\text { Probability } \\
\& \text { Statistic }\end{array}$ & $\begin{array}{l}\text { Considered but } \\
\text { not sufficiently }\end{array}$ \\
\hline & $\begin{array}{l}\text { ITPAB, IIT, } \\
\text { ITCANCUN, ITL }\end{array}$ & Economic-Administrative & Statistic & $\begin{array}{l}\text { Considered } \\
\text { sufficiently. }\end{array}$ \\
\hline \multirow[t]{2}{*}{7} & $\begin{array}{l}\text { UNISON, UNAM, } \\
\text { UACH, UMICH }\end{array}$ & Biological -Agricultural & & Not considered \\
\hline & $\begin{array}{l}\text { ITD, IIT, ITCG, } \\
\text { ITCHET, ITPAB, ITT, } \\
\text { ITCOMITAN, ITE, } \\
\text { ITGRULLO, ITNL }\end{array}$ & Exact Sciences & $\begin{array}{l}\text { Probability } \\
\text { \& Statistic }\end{array}$ & $\begin{array}{l}\text { Considered } \\
\text { sufficiently. }\end{array}$ \\
\hline
\end{tabular}

Figure 3. Colorimeter constructed from correspondence analysis of MAE care in the programs analyzed.

Figure 3 shows in red the goals identified as not met. It specifies in which course the academic area belonged and the institution where it was taught. In yellow, appears the goals that were moderately met and in green those that were met. The table indicates which institution, and area programs to which the goals were associated. It can be seen that the administrative and exact economic areas are the ones that best met the goals listed, which is understandable since there was a greater tradition of statistics related to the disciplines of these areas. It should be noted that interpretations of statistical studies are common in areas such as marketing, management, finance, industrial design, and logistics. Goals 3, 6 and 8 had no significant association, so they were not included in the colorimeter.

\section{CONCLUSIONS AND RECOMMENDATIONS}

The analysis shows that at the time of the study there was a severe problem in Mexican statistical education. Gal and Garfield (1997) specified that the MAEs were divided into two groups: those of "doing" and those of "thinking". Since most of the courses concentrate their contents in the "do" category, leaving statistical thinking aside, we can understand the magnitude of the problem. We agree with Batanero $(2000,2019)$ that the analysis of the curriculum must be carried out in order to take improvement actions if, from the academies of professors, the statistics subject programs are restructured, taking into account the MAE to develop the statistical thinking and the competences for 
the use of the statistical methodology. Should this occur, a great change would be generated because the programs are the basis of the courses. This must somehow be initiated because social claims are increasing. The managers of HEIs must take action on the matter.

If we take the research conducted by Wild and Pfannkuch (1999) as a reference, which indicated that the application of statistics involves the formulation of questions and the discussion of the results, we see that in the courses that only focus on data processing are lacking. We conclude that the statistical education that is being taught is insufficient because the students finish without knowing what the data analysis implies. In Wild and Pfannkuch's dimension 2 of statistical thought, mention is made of decision making under uncertainty and variation as a central element for statistics. If the understanding of these concepts is omitted from the course program, there is the potential students will not be able to find out what it means to make decisions in contexts of uncertainty, which is fundamental in statistics.

It was also observed that the courses were focusing only on the calculation of probabilities, without students understanding the importance of stochastic concepts and the usefulness they have in everyday life (Batanero 2019). Likewise, it is known that statistical thinking implies the extraction of the information contained in the data in order to reach the knowledge, so it is necessary to establish connections among the existing knowledge and the results of the analyses, since in that way students will reach significant conclusions. Unfortunatley, these aspects of working with data (considered in Goal 7) were left out of many programs. It appears appreciation for statistics (Goal 8) and reasoning in the research cycle were not promoted, so students were not trained fully as statistically literate professionals, capable of conducting research and technical studies with the help of statistics.

It should be noted that the severity of the problem is differentiated by areas of knowledge: in health sciences it is very serious; it is serious in social and agricultural sciences; and to a lesser degree in exact and administrative sciences, where there is a tradition of profusely using statistics in various specialties or subjects of careers that are located in these areas. This behavior was as expected. In this regard, it is noteworthy that in the System of Technological Institutes of the country the program of the subject of statistics was designed with the approach of competences, so it was detected where the most complete programs that contemplated the MAEs, which constitute examples to be followed by the rest of the Mexican HEIs.

\section{REFERENCES}

Bailey, B., Spence, D., \& Sinn, R. (2013). Implementation of discovery projects in statistics. Journal of Statistics Education, 21(3). https://doi.org/10.1080/10691898.2013.11889682

Ballman, K. (1997). Greater emphasis on variation in an introductory statistics course. Journal of Statistics Education, 5(2). https://doi.org/10.1080/10691898.1997.11910529

Batanero, C. (2000). ¿Hacia dónde va la educación estadística? [Where is statistical education going?] Blaix, 15, 2-13.

Batanero, C. (2001). Didáctica de la estadística. [Didactics of statistics] Universidad de Granada.

Batanero, C. (2019). Treinta años de investigación en educación estocástica: Reflexiones y desafíos. [Thirty years of research in stochastic education: Reflections and challenges] In J. M. Contreras, M. M. Gea, M. M. López-Martín \& E. Molina-Portillo (Eds.), Actas del Tercer Congreso Internacional Virtual de Educación Estadística. [Proceedings of the Third Virtual International Congress on Statistical Education] http://www.ugr.es/local/fqm126/civeest.html

Behar, R., \& Ojeda, M. M. (2016). El papel de algunas opciones tecnológicas en la educación estadística. [The role of some technological options in statistical education] Heuristica, 18, 21-35.

Biehler, R. (2018). Design principles, realizations and uses of software supporting the learning and the doing of statistics: A reflection on developments since the late 1990s. In M. A. Sorto, A. White, \& L. Guyot (Eds.), Looking back, looking forward. Proceedings of the Tenth International Conference on Teaching Statistics (ICOTS10, July 8-13), Kyoto, Japan. https://iaseweb.org/icots/10/proceedings/pdfs/ICOTS10_1B1.pdf

Boterf, L. G. (2000). Compétence et navigation professionnelle. [Competence and professional navigation] Éditions d'organisation.

Castillo, G. (1989). Innovación educativa y programa de curso. [Educational innovation and course program] CPEIP. 
Cruz, C., \& Ojeda, M. M. (2016). Uso de las metas de aprendizaje en los cursos introductorios de estadística en la Universidad Veracruzana. [Use of learning goals in introductory statistics courses at the University of Veracruzana] Heuristica, 18, 1-13.

Cruz, C., \& Ojeda, M. M. (2018). La opinión de los estudiantes sobre el uso de las metas de aprendizaje de la estadística en cursos introductorios en la Universidad Veracruzana. [The opinion of the students on the use of the learning goals of statistics in introductory courses at the University of Veracruzana] Investigación Operacional, 39(2), 181-191.

Díaz-Barriga, F. (2005). Desarrollo del currículo e innovación: Modelos e investigación en los noventa. [Curriculum development and innovation: Models and research in the 1990s] Perfiles Educativos, 27(107), 57-84.

Figueroa, G., \& Larios, I. (2005). Propuesta de cambios en los contenidos y métodos de enseñanza para un curso introductorio de estadística. [Proposal for changes in the contents and teaching methods for an introductory statistics course] Memorias de la XV Semana Regional de Investigación y Docencia en Matemáticas. [Memories of the XV regional week of research and teaching in mathematics] Universidad de Sonora.

Gal, I., \& Garfield, J. (1997). Curricular goals and assessment challenges. In I. Gal \& J. Garfield (Eds.), The assessment challenge in statistics education (pp. 1-14). IOS Press.

Garfield, J. (1995). How students learn statistics. International Statistical Review, 63(1), 25-34.

Garfield, J., \& Gal, I. (1999). Assessment and statistics education: Current challenges and directions. International Statistical Review, 67(1), 1-12.

Gundlach, E., Richards, K. A., Nelson, D., \& Levesque-Bristol, C. (2015). A comparison of student attitudes, statistical reasoning, performance, and perceptions for web-augmented traditional, fully online, and flipped sections of a statistical literacy class. Journal of Statistics Education, 23(1). http://www.amstat.org/publications/jse/v23n1/gundlach.pdf

Hassad, R. A. (2003). Teaching introductory statistics in the social and behavioral sciences: Approach and rationale. In proceedings of the 2003 Joint Statistical Meetings: Section on Teaching Statistics in Health Science (pp. 1783-1788). https://files.eric.ed.gov/fulltext/ED506521.pdf

Izumi, S., \& Hatayama, M. (2018). Overview of an educational model of elementary statistics for the data science program of Shiga University. In M. A. Sorto, A. White \& L. Guyot (Eds.), Looking back, looking forward. Proceedings of the Tenth International Conference on Teaching Statistics (ICOTS10, July 8-13), Kyoto, Japan. http://iase-web.org/icots/10/proceedings/pdfs/ICOTS10_1A1.pdf?1531364185

Juárez, A. J., \& Inzunsa, S. (2014). Comprensión y razonamiento de profesores de matemáticas de bachillerato sobre conceptos estadísticos básicos. [High school math teachers understanding and reasoning about basic statistical concepts] Perfiles educativos, 36(146), 14-29.

Lyford, A., \& Kaplan, J. (2018). Improving student learning and instructional effectiveness through the innovative use of automated analysis of formative assessments. In M. A. Sorto, A. White \& L. Guyot (Eds.), Looking back, looking forward. Proceedings of the Tenth International Conference on Teaching Statistics (ICOTS10, July 8-13), Kyoto, Japan. http://iaseweb.org/icots/10/proceedings/pdfs/ICOTS10_1E1.pdf?1531382515

McNamara, A. (2018). Imagining the future of statistical education software. In M. A. Sorto, A. White \& L. Guyot (Eds.), Looking back, looking forward. Proceedings of the Tenth International Conference on Teaching Statistics (ICOTS10, July 8-13), Kyoto, Japan. http://iaseweb.org/icots/10/proceedings/pdfs/ICOTS10_1B2.pdf?1531364185

Méndez, M. A., \& Ojeda, M. M. (2006). Evaluación de profesores de nivel superior usando metas de aprendizaje en estadística. [Higher level teacher assessment using statistical learning Goals] Revista Heurística, 13, 53-60.

Moore, D. S. (1993). A generation of statistics education: An interview with Frederick Mosteller. Journal of Statistics Education, 1(1). https://doi.org/10.1080/10691898.1993.11910453

Palomo, R., Ruiz, J., \& Sánchez, J. (2006). Las TIC como agentes de innovación educativa. [ICT as agents of educational innovation]. Sevilla: Junta de Andalucía, Consejería de Educación, Dirección General de Innovación Educativa y Formación del Profesorado.

Romero, M. M. (2003). La metamorfosis del cambio educativo (7th Ed.). [The metamorphosis of educational change] Ediciones Akal. 
Romero, M. M. (2008). Los avatares del cambio educativo: Buscando alternativas al persistente "consenso" tecnológico. [The avatars of educational change: Looking for alternatives to the persistent technological "consensus"]. In M. de la Torre (Ed.), Concepciones y representaciones del cambio educativo [Concepts and representaions of educational change] (pp. 54-108). Universidad de Nuevo León.

Universidades de México. (2015). Lista de universidades privadas y públicas de México ordenadas por región. [List of private and public universities in Mexico sorted by region] https://www.altillo.com/universidades/universidades_mex.asp

Vivacqua, C., S de Pinho, A.L., Nunes, M., \& Vance E. (2018). Integrating collaboration, communication and problem solving to promote innovation in statistics education. In M. A. Sorto, A. White \& L. Guyot (Eds.), Looking back, looking forward. Proceedings of the Tenth International Conference on Teaching Statistics (ICOTS10, July 8-13), Kyoto, Japan. http://iaseweb.org/icots/10/proceedings/pdfs/ICOTS10_5G2.pdf?1531364272

Wild, C. J., \& Pfannkuch, M. (1999). Statistical thinking in empirical enquiry. International Statistical Review, 67(3), 223-248.

CECILIA CRUZ LÓPEZ

Manzano \# 27

Infonavit Sumidero

Xalapa, Veracruz, México

C.P. 91157 